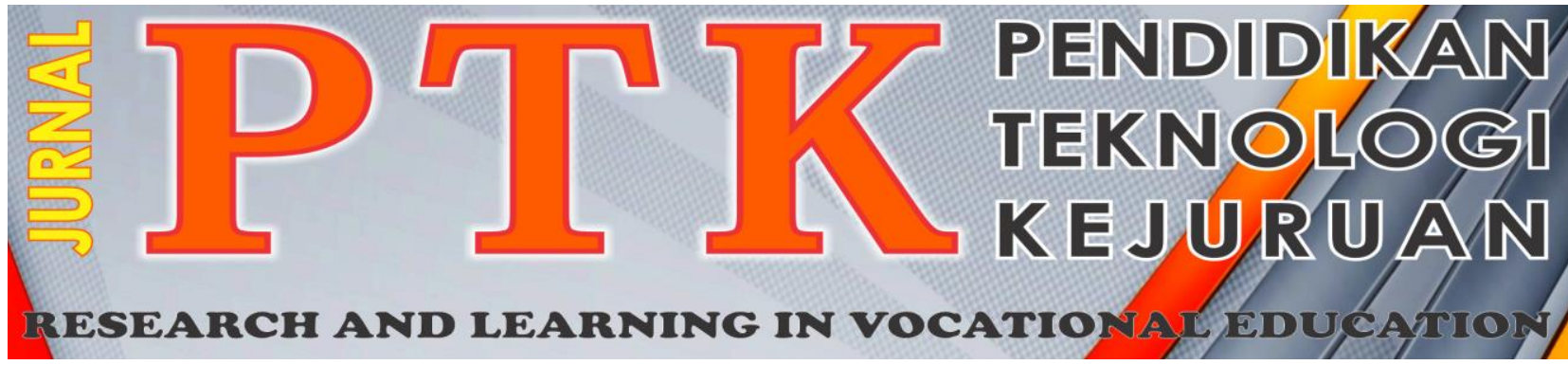

Vol. 2, No. 3, 2019

P-ISSN: 2621-3273

E-ISSN: 2621-1548

\title{
Pemanfaatan Motor Listrik Bertenaga Energi Matahari Sebagai Penarik Jaring Pada Kapal Nelayan
}

\author{
Ali Basrah Pulungan ${ }^{1 *}$, Asnil ${ }^{1}$, Rahmat Hidayat ${ }^{1}$, Juli Sardi ${ }^{1}$, Syaiful Islami ${ }^{1}$ \\ ${ }^{1}$ Jurusan Teknik Elektro, Fakultas Teknik, Universitas Negeri Padang \\ ${ }^{*}$ Corresponding author, e-mail: alibp@ft.unp.ac.id ${ }^{1}$
}

\begin{abstract}
Abstrak - Artikel bertujuan untuk dapat memanfatkan motor listrik sebagai penarik jaring pada kapal nelayan mengunakan energi matahari. Penggunaan tenaga manusia sebagai penarik jaring membutuhkan tenaga yang besar dan butuh istirahat untuk dapat melakukan aktifitas penarikan lagi, sehingga jumlah penarikan yang dapat dilakukan sangat terbatas. Kelompok nelayan Pantai Jaya sebagai mitra merupakan satu diantara 20 kelompok nelayan yang aktif dikelurahaan Pasie Nan Tigo kecamatan Koto Tangah Kota Padang yang mengalami permasalahan tersebut. Permasalahan mitra ini dapat diberikan solusi berupa pemanfaatan motor listrik sebagai penarik jaring pada kapal nelayan. Agar tidak menimbulkan masalah dalam hal penyediaan tenaga listrik dapat digunakan energi matahari dengan mengunakan solar cell, sehingga tidak ada penambahan bahan bakar minyak. Metode pelaksanaan yang diberikan yaitu melakukan pemasangan langsung dan pemberian materi penyuluhan tentang pemanfaatan teknologi solar cell serta pengenalan komponen-komponen dan hand tools. Kegiatan ini dilaksanakan selama dua hari yang meliputi persiapan, pemasangan dan pelatihan, diikuti satu kelompok nelayan. Kelompok nelayan menerima satu set solar cell, motor listrik, baterai dan kelengkapan lainnya dan terpasang. Berdasarkan pengujian yang telah dilakukan pada keadaan cuaca cerah suhu $30^{\circ} \mathrm{C}$, beban $50 \mathrm{~kg}$ dengan tegangan yang terukur pada saat itu 12,4V, kecepatan motor 2,7m/menit, 2,4A. Berdasarkan hasil pengujian tersebut menunjukkan bahwa sistem solar cell telah bekerja sesuai parameter yang seharusnya. Oleh karena itu, dapat dikatakan bahwa kegiatan ini telah terlaksana dengan baik dan sistem solar cell sudah berfungsi dengan benar. Peserta berharap untuk kegiatan tersebut dapat dilaksanakan untuk tahun berikutnya, karena masih ada beberapa kapal kelompok nelayan yang sangat membutuhkan.
\end{abstract}

Kata kunci : solar cell, motor listrik, kapal nelayan, kelompok nelayan

Abstract-This article aim to be able to take advantage of an electric motor as a net puller on a fishing boat using solar energy. The use of human labor as a net puller requires a large amount of energy and needs a break to be able to do more withdrawal activities, so the number of withdrawals that can be done is very limited. Pantai Jaya fishing groups as partners are among the 20 active fishing groups in the Pasie Nan Tigo sub-district of Koto Tangah subdistrict of Padang City who experience these problems. The problem of this partner can be given a solution in the form of the use of an electric motor as a towing net on a fishing boat. In order not to cause problems in terms of electricity supply, solar energy can be used by using solar cells, so there is no addition of fuel oil. The implementation method given is direct installation and provision of extension materials on the use of solar cell technology and the introduction of components and hand tools. This activity was carried out for two days which included preparation, installation and training, followed by a group of fishermen. The fishing group received a set of solar cells, electric motors, batteries and other accessories and installed them. Based on tests that have been carried out in sunny weather conditions at 300C, a load of $50 \mathrm{~kg}$ with a rated voltage at that time $12.4 \mathrm{~V}$, motor speed $2.7 \mathrm{~m} / \mathrm{min}, 2.4 A$. Based on the results of these tests indicate that the solar cell system has worked according to the parameters it should. Therefore, it can be said that this activity has been carried out properly and the solar cell system is functioning properly. Participants hope for these activities to be carried out for the following year, because there are still a number of fishing boat groups that are in dire need..

Keywords： solar cell, electric motor, fishing boat, fishing group 


\section{Pendahuluan}

Sumber energi fosil yang terus menipis dan kebutuhan energi yang terus meningkat, telah mendorong pengembangan dan pemanfaatan sumber energi baru yang lebih efisien dan hijau, seperti angin, mikrohidro, panas bumi, biomassa, biogas dan cahaya matahari. Cahaya matahari telah dimanfaatkan manusia sejak lama sebagai sumber energi dengan menggunakan berbagai teknologi mulai dari sederhana sampai yang canggih. Hal ini disebabkan bahwa matahari sebagai sumber energi yang dapat mensuplai energi sekitar 27.000 kali jumlah energi yang dihasilkan dari semua sumber lainnya [1]. Teknologi saat ini memungkinkan konversi radiasi matahari menjadi energi listrik yang dikenal sebagai sistem fotovoltaik. Sistem konversi ini diharapkan dapat memberikan kontribusi signifikan untuk memecahkan beberapa masalah energi yang dihadapi dunia saat ini.

Pertumbuhan konsumsi energi di Indonesia rata-rata $8.1 \%$ pertahun, belum berimbang dengan pertumbuhan pembangkitan energi listrik yang hanya tumbuh rata-rata $5.2 \%$ per tahun [2]. Ketergantungan terhadap energi fosil masih tinggi yaitu 95.4\%, cadangannya semakin terbatas. Pemanfaatan sumber energi baru terbarukan adalah salah satu alternatif untuk menggantikan posisi energi fosil. Energi surya sebagai sumber energi terbarukan dapat dikembangkan untuk pembangkit tenaga listrik yang berdiri sendiri atau disalurkan melalui jaringan listrik secara interkoneksi terutama pada daerah katulistiwa khususnya Indonesia [3]. Indonesia berada di daerah tropis mempunyai potensi energi surya sangat besar sekitar rata-rata 4,8 $\mathrm{kWh} / \mathrm{m} 2 /$ hari atau setara dengan $112.000 \mathrm{GWp}$, namun yang sudah dimanfaatkan baru sekitar 71,02 MWp baik yang terintrkoneksi dan off-grid [4]. Selain itu, pada daerah tropis variasi sudut azimuth sinar matahari kecil [5], sehingga khusus pemasangan di atas atap kapal nelayan tidak dibutuhkan solar tracking.

Pemanfaatan energi baru terbarukan juga dapat dikembangkan bagi nelayan yang sehari-harinya berada di pesisir pantai dengan tingkat pencahayaan matahari yang sangat tinggi. Kota Padang merupakan salah satu kota besar di Indonesia yang terletak di pesisir barat Pulau Sumatera dengan garis pantai sepanjang $84 \mathrm{~km}$ dan luas wilayah perairan sekitar $720 \mathrm{~km}^{2}$. Menurut data BPS, jumlah penduduk Kota Padang yang berprofesi sebagai nelayan pada tahun 2016 adalah 7076 jiwa yang tersebar di tujuh kecamatan. Kelurahan Pasie Nan Tigo merupakan salah satu kelurahan yang terletak di Kecamatan Koto Tangah Kota Padang. Kelurahan Pasie Nan Tigo merupakan salah satu desa nelayan yang terletak di Kecamatan Koto Tangah Kota Padang. Dari data yang didapatkan dari kantor Kelurahan Pasie Nan Tigo, jumlah nelayan yang terdapat pada daerah tersebut berjumlah 1456 jiwa, dengan kata lain hampir $70 \%$ nelayan yang ada di Kecamatan Koto Tangah berasal dari Kelurahan Pasie Nan Tigo. Jenis kapal yang dioperasikan nelayan di kelurahan ini adalah bagan, tondo dan pompong.

Kelurahan Pasie Nan Tigo memiliki 20 Kelompok Nelayan, satu diantaranya yang aktif adalah Kelompok Nelayan Pantai Jaya. Kelompok Nelayan ini berdiri sejak tahun 2014 dengan jumlah anggota saat ini 15 orang dan memiliki aset produksi 6 kapal motor jenis Tondo, 6 kapal mesin dompeng jenis pompong. Produksi unggulan yang dihasilkan adalah ikan tongkol/pelagis, ikan karang/ikan kakap.

Universitas Negeri Padang sebagai salah satu perguruan tinggi pendidikan dan vokasi terkemuka di Indonesia, memiliki pengalaman yang panjang dalam pelaksanaan kegiatan pengabdian kepada masyarakat sebagai wujud peran aktif untuk membantu mengatasi berbagai permasalahan yang ada pada masyarakat. Dalam hal ini, tim pengabdian merencanakan melaksanakan kegiatan untuk para nelayan berupa pemanfaatan motor listrik sebagai penarik jaring pada kapal nelayan di Kelurahan Pasie Nan Tigo. Kegiatan ini dilaksanakan berdasarkan pertimbangan bahwa penarik jaring pada kapal nelayan masih menggunakan tenaga manusia, sehingga tidak maksimal, di samping itu ketersedian sinar matahari yang banyak sepanjang tahun, energi ramah lingkungan, tidak adanya biaya investasi lahan dan mengurangi ketergantungan akan energi fosil [6][7][8].

Kegiatan ini bertujuan meningkatkan hasil tangkapan ikan oleh nelayan tanpa menambah biaya operasional berupa kebutuhan bahan bakar minyak solar. Penggunaan solar cell ini nantinya dapat dimanfaatkan dengan baik sehingga akan meningkatkan kesejahteraan nelayan.

\section{METODE}

Dari permasalahan yang diuraikan tersebut terdapat peluang pemanfaatan motor listrik sebagai penarik jaring pada kapal nelayan menggunakan energi matahari. Penggunaan motor listrik dapat menggantikan tenaga manusia pada saat penarikan jaring pada kapal nelayan, juga Solar cell sebagai alat konversi energi matahari menjadi energi listrik, dapat menghindari penambahan biaya operasional ketika pergi melaut untuk menangkap ikan..

Metode pelaksanaan yang diberikan yaitu melakukan pemasangan langsung dan pemberian materi penyuluhan tentang pemanfaatan teknologi solar cell serta pengenalan komponen-komponen 
dan hand tools. Kegiatan ini dilaksanakan selama dua hari yang meliputi persiapan, pemasangan dan pelatihan, diikuti satu kelompok nelayan.

Panel surya dipasang di atap kapal secara horizontal dengan tujuan agar radiasi sinar matahari yang diperoleh maksimum sehingga didapatkan output tegangan yang optimal.

Sistem pembangkit listrik menngunakan solar cell terdiri dari solar cell (panel surya), charger controller, baterai, saklar dan motor listrik

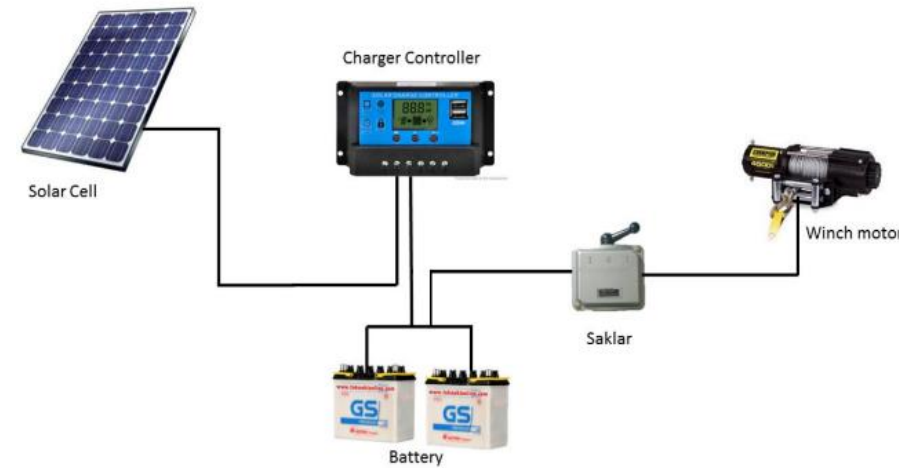

Gambar 1. Skema rangkaian pembangkit listrik menggunakan solar cell

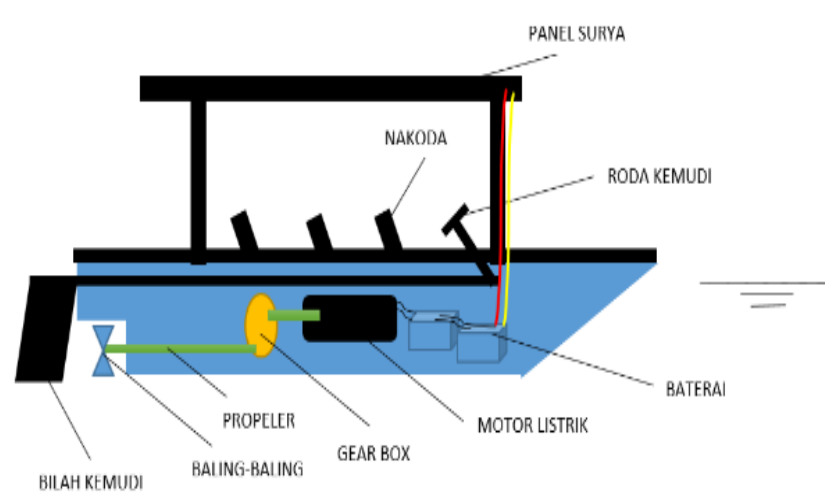

Gambar 2. Skema Pemasangan Panel Surya (Solar Cell) pada Kapal Nelayan

Tabel 1. Spesifikasi komponen sistem solar cell yang digunakan

\begin{tabular}{|l|l|l|l|}
\hline No. & $\begin{array}{l}\text { Nama } \\
\text { Komponen }\end{array}$ & $\begin{array}{l}\text { Jumlah } \\
\text { (buah) }\end{array}$ & Spesifikasi \\
\hline 1. & Solar Panel & 1 & $\begin{array}{l}\text { 250 WP Mono } \\
\text { Crystalline }\end{array}$ \\
\hline 2. & $\begin{array}{l}\text { Charger } \\
\text { Controller }\end{array}$ & 1 & $\begin{array}{l}\text { 12 VDC, 30A, 390 } \\
\text { W }\end{array}$ \\
\hline 3. & Baterai & 2 & $\begin{array}{l}\text { 12V 60Ah, 12V } \\
\text { 50Ah }\end{array}$ \\
\hline 4. & $\begin{array}{l}\text { Motor } \\
\text { Listrik }\end{array}$ & 1 & $\begin{array}{l}\text { 1300lb, 12 VDC, } \\
0,52 \mathrm{~kW}\end{array}$ \\
\hline 5. & Saklar & 1 & Forward/Reverse \\
\hline 6. & Kabel & $20 \mathrm{~m}$ & $3 \times 1,5 \mathrm{~mm}$ \\
\hline
\end{tabular}

Rencana kegiatan yang dilakukan adalah sebagai berikut :

1. Pengenalan komponen dan fungsinya

2. Pemasangan dan perawatan solar cell.

3. Penggunaan hand tools pada pemasangan solar cell

4. Pelaksanaan pemasangan solar cell pada atap kapal

5. Pengujian dan pengukuran besaran yang dihasilkan seperti tegangan dan arus

\section{HASIL DAN PEMBAHASAN}

Kegiatan diikuti oleh satu kelompok nelayan, pelaksanaan kegiatan berjalan lancar sebagaimana yang direncanakan hal ini terlihat dengan tepasangnya motor listrik, solar cell dan baterai serta kelengkapan lainnya di kapal kelompok nelayan. Hasil yang diperoleh dari kegiatan dapat diuraikan dalam beberapa aspek, seperti aspek pengetahuan, keterampilan dan produk.

Berdasarkan diskusi dan tanya jawab yang dilakukan dengan anggota nelayan selama pelaksanaan kegiatan menunjukkan adanya peningkatan pengetahuan tentang motor listrik, sinar matahari dengan menggunakan solar cell. Nelayan juga dapat mengetahui nilai tegangan yang terdapat pada baterai dan yang ditunjukkan pada charger controller. Peningkatan keterampilan juga dapat terlihat dari pengamatan pada saat pemasangan, para anggota nelayan antusias untuk dapat melakukan pemasangan sendiri, seperti pangawatan pada baterai dan charger controller.

Pengujian produk yaitu pengujian motor listrik menggunakan energi matahari melalui solar cell yang telah dipasang. Setelah selesai pemasangan pada kapal nelayan, dilakukan pengujian dengan tujuan untuk memastikan bahwa motor listrik dan sistem solar cell telah bekerja dan berfungsi baik, hal ini dapat dibuktikan melakukan pengukuran parameter pada motor listrik dan solar cell. Pengujian dilakukan pada cuaca cerah suhu 300C, beban $50 \mathrm{~kg}$ dengan tegangan yang terukur pada saat itu $12,4 \mathrm{~V}$, kecepatan motor $2,7 \mathrm{~m} /$ menit, 2,4A. Berdasarkan hasil pengujian tersebut menunjukkan bahwa motor listrik dan sistem solar cell telah bekerja baik sesuai parameter yang seharusnya. 
Berikut ini beberapa dokumentasi kegiatan:

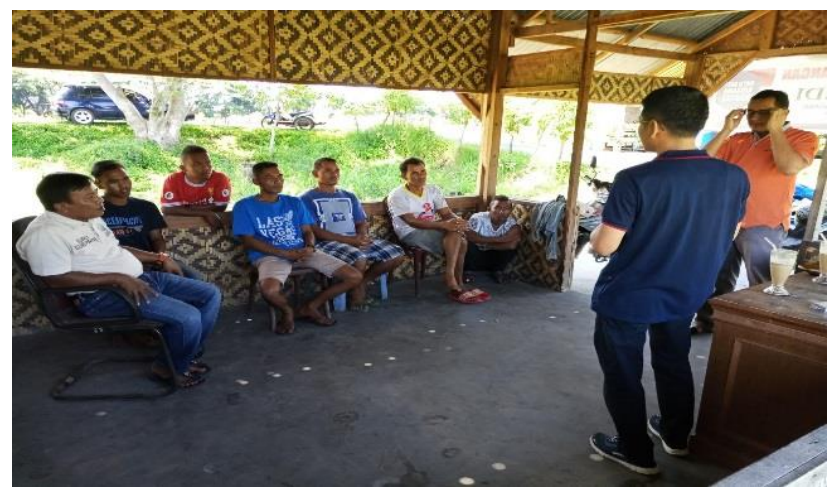

Gambar 3. Pemberian materi sumber energi baru dan terbarukan

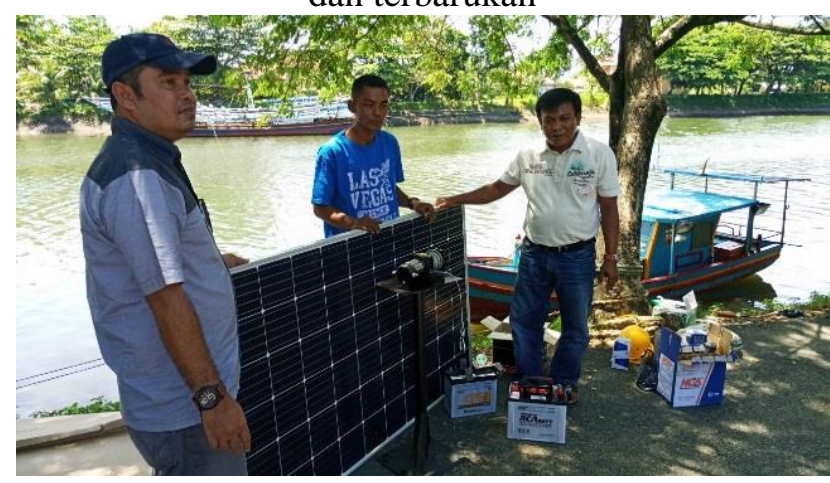

Gambar 4. Serah terima peralatan

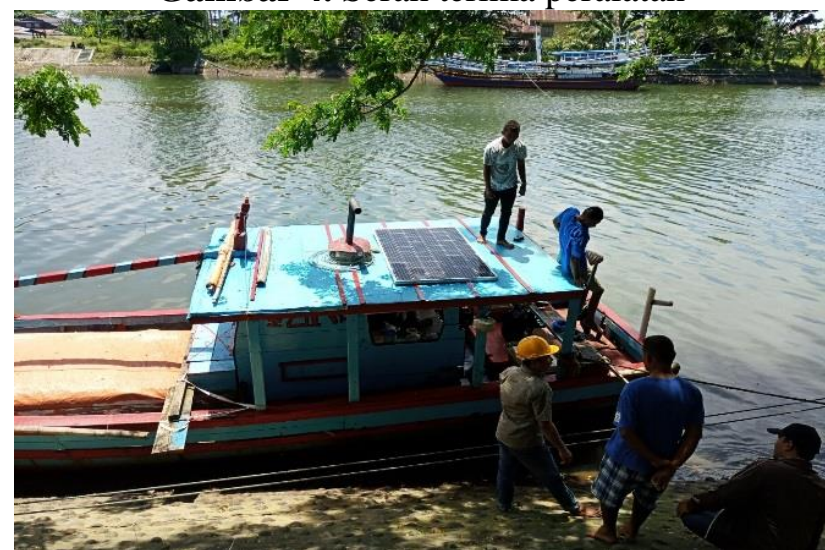

Gambar 5. Pemasangan solar cell di kapal nelayan

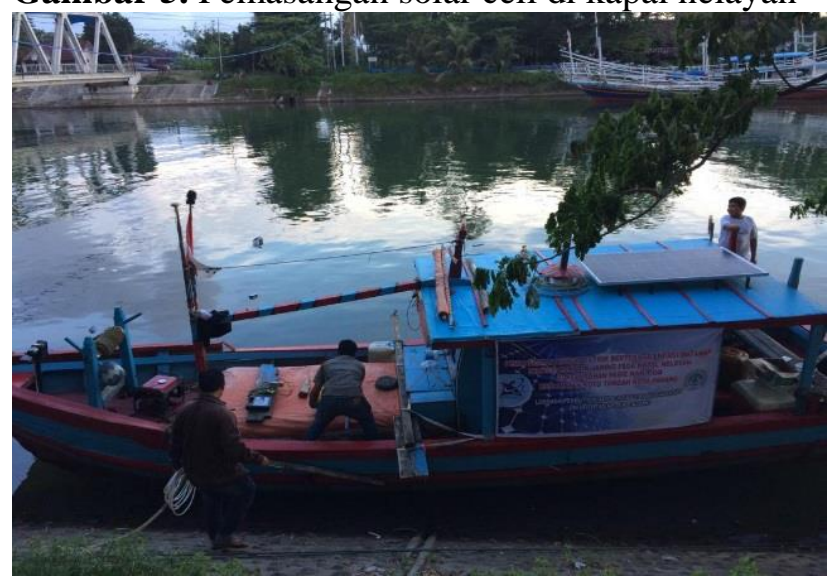

Gambar 6. Pemasangan kabel listrik oleh Nelayan dan Tim Pengabdian

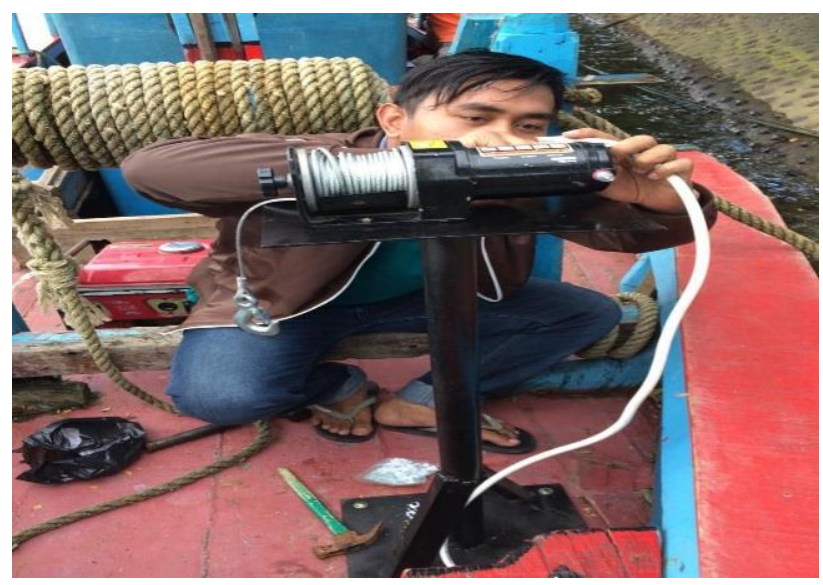

Gambar 7. Pemasangan kabel pada motor litrik

Selama pelaksanaan pelatihan para peserta sangat antusias dan tidak ditemukan kendala yang berarti. Para peserta telah dapat mengoperasikan motor listrik dan sistem solar cell yang telah terpasang.

\section{KESIMPULAN}

Kegiatan pemanfaatan motor listrik bertenaga energi matahari sebagai penarik jaring pada kapal nelayan di kelurahan Pasie Nan Tigo kecamatan Koto Tangah kota Padang telah selesai dilaksanakan, dan telah dilakukan pengujian dan pengukuran besaran yang ada. berdasarkan hasil tersebut, solar cell dan seluruh komponen lainnya telah berfungsi dengan baik dan benar serta telah dapat dipergunakan oleh kelompok nelayan.

\section{Daftar Pustaka}

[1] A. Catalin, "The Design and Optimization of a Photovoltaic Tracking Mechanism," in POWERENG 2009, Lisbon, Portugal, 2009.

[2] RUPTL, Rencana Usaha Penyedia Tenaga Listrik PT PLN (Persero) Tahun 2016 s.d. 2025. 2016.

[3] W. Yandi, Syafii, and A. B. Pulungan, "Tracker Tiga Posisi Panel Surya Untuk Peningkatan Konversi Energi Dengan Catu Daya Rendah," J. Nas. Tek. Elektro, vol. 6, no. 3, pp. 159-167, 2017.

[4] Republik Indonesia, Rencana Strategis Kementrian Energi dan Sumber Daya Mineral (Renstra KESDM). 2015.

[5] H. J. Loschi, Y. Iano, and J. Leon, "A review on photovoltaic system: Mechanisms and Methods for Irradiation Tracking and Prediction," Smart Grid Renew. Energy, vol. 6, pp. 187-208, 2015.

[6] S. Hagerman, P. Jaramillo, and M. G. Morgan, "Is rooftop solar PV at socket parity without subsidier," Energy Policy, vol. 89, pp. 89-94, 2016.

Jurnal PTK: Research and Learning in Vocational Education 
[7] S. Yondri, R. A. Nabawi, Fibriyanti, Firmansyah, Herisajani, and S. Islami, "Utilization of Potential Water Energy in Irrigation Channels for PicoHydro Power Plant," in International Conference of Applied Science on Engineering, Business, Linguistics and Information Technology, 2017.

[8] A. B. Pulungan, J. Sardi, Hastuti, S. Islami, and Hamdani, "Pemasangan Solar Cell untuk Kapal Nelayan," J. Inf. Technol. Comput. Sci., vol. 2, no. 2, pp. 1-6, 2019. 